\title{
APPLICATION OF THE AI CHI METHOD IN REHABILITATION - STATE OF THE ART BASED ON A REVIEW OF LITERATURE
}

\author{
ZASTOSOWANIE METODY AI CHI W REHABILITACJI - STAN WIEDZY OPARTY NA \\ PRZEGLĄDZIE LITERATURY
}

Sebastian Nonn-Wasztan ${ }^{1}$, Małgorzata Zgorzalewicz-Stachowiak², Anna Kostiukow ${ }^{1}$, Krystyna Zeńczak-Praga ${ }^{2}$, Piotr Poniewierski1 ${ }^{1}$, Włodzimierz Samborski ${ }^{1}$, Elżbieta Rostkowska ${ }^{3}$

'Department of Rheumatology and Rehabilitation, Poznan University of Medical Science, Poznań, Poland

${ }^{2}$ Department of Health Prophylaxis, Laboratory of Medical Electrodiagnostics, Poznan University of Medical Science, Poznań, Poland

${ }^{3}$ Faculty of Pedagogy and Health Promotion, The University of Computer Science and Skills, Łódź, Poland

\section{ABSTRACT}

\section{Introduction}

Aquatic therapy is most widely applied in the rehabilitation of patients with musculoskeletal system dysfunction. The horizontal position of the body in water changes the blood circulation from vertical (up/down) to horizontal. It also takes weight off the spine thereby significantly changing the work of the muscles and contributing to pain relief. Moreover, the level of anxiety and stress is decreased because water at the right temperature has a relaxing effect.

\section{Aim}

The purpose of the study was to assess the effectiveness of the Ai Chi method in the rehabilitation of patients struggling with various medical conditions.

\section{Material and methods}

A systematic review of articles in the PubMed browser from 1994 under the password "Ai Chi, rehabilitation, water rehabilitation" was used in the article.

\section{Results}

A review of the scientific literature confirms the applicability of conducting the Ai Chi method. Outcome measures include the evaluation of $\mathrm{Ai}$ Chi in medical condition as follows: balance disorder in seniors, lower back pain (LBP), multiple sclerosis (MS), stroke, fibromyalgia, Parkinson's disease (sequence of diseases in random order).

\section{Conclusions}

One of the most significant results is the improvement in the ability to maintain body balance. Several authors showed that 8-weeks lasting Ai Chi program improved the balance, motor control, strength of upper and lower limbs and lowered fatigue in patients only exercising in water (patients with MS). The authors emphasize the advantages of the Ai Chi method 
conducted in water accompanied by music as more effective than conventional kinesiotherapy. The presented work emphasizes the beneficial effect of the Ai Chi method on the maintenance of static and dynamic body balance, especially in older adults.

Keywords: Ai Chi, rehabilitation, water rehabilitation

\section{STRESZCZENIE}

\section{Wstęp}

Terapia w środowisku wodnym jest najczęściej stosowaną formą rehabilitacji w terapii pacjentów z zaburzeniami układu mięśniowo-szkieletowego. Pozioma pozycja ciała w wodzie zmienia krążenie krwi z pionowej (w górę/w dół) na poziomą. Odciąża również kręgosłup, co znacznie zmienia pracę mięśni i przyczynia się do łagodzenia bólu. Co więcej, poziom lęku i stresu jest obniżony, ponieważ woda o odpowiedniej temperaturze ma działanie relaksujące.

Cel

Celem pracy była ocena skuteczności metody Ai Chi w rehabilitacji pacjentów zmagających się z różnymi schorzeniami.

\section{Materiał i metody}

W artykule wykorzystano systematyczny przegląd artykułów wykonany w bazie PubMed od 1994 roku pod hasłami „Ai Chi, rehabilitacja, rehabilitacja w środowisku wodnym”.

\section{Wyniki}

Przegląd literatury naukowej potwierdza możliwość zastosowania metody Ai Chi. Analizowane publikacje dotyczą wykorzystania Ai Chi w: zaburzeniach równowagi u seniorów, bólach odcinaka lędźwiowego kręgosłupa, stwardnieniu rozsianym, udarze mózgu, fibromialgii, chorobie Parkinsona (schorzenia wymienione w przypadkowej kolejności).

\section{Wnioski}

Jednym z najbardziej znaczących rezultatów jest poprawa zdolności do utrzymania równowagi ciała. Kilku autorów wykazało, że trwający 8 tygodni cykl terapeutyczny z wykorzystaniem Ai Chi poprawił równowagę, kontrolę motoryczną, siłę kończyn górnych i dolnych oraz zmniejszył zmęczenie u pacjentów ćwiczących tylko w wodzie (pacjenci ze stwardnieniem rozsianym). Autorzy podkreślają zalety metody Ai Chi przeprowadzanej w wodzie w towarzystwie muzyki jako skuteczniejszej niż konwencjonalna kinezyterapia. Prezentowana praca podkreśla korzystny wpływ metody Ai Chi na utrzymanie statycznej i dynamicznej równowagi ciała, szczególnie u osób starszych.

Słowa kluczowe: Ai Chi, rehabilitacja, rehabilitacja w środowisku wodnym

\section{Introduction}

An aquatic environment creates favorable conditions for multidirectional impact on the human body. Therapy in water helps to optimize the process of rehabilitating musculoskeletal disorders. It can be used as a supplement to the treatment process at any stage because it allows early mobilization and improvement of neuromuscular control in patients undergoing therapy (Becker 2009). The influence of water - in particular, its properties such as temperature, resistance, hydrostatic pressure, buoyancy force, and 
waves - are beneficial for the body. It is believed that systematic exercise performed in water may help to maintain or develop muscle strength, keep movement within its proper range or increase the range of motion in joints affected by reduced mobility. Swimming movements provide an opportunity for gentle stretching, with the additional benefit of alternating stretching with the loosening of muscles. The level of anxiety and stress caused by the patient's overall health concerns is reduced. The patient is able to assume body positions in the water that would be otherwise be impossible. The buoyancy of the water supports the body, while also improving blood circulation. The horizontal position of the body in the water changes the blood circulation from vertical orientation (up/down) to horizontal orientation, which improves the blood circulation around an organism that normally experiences poor circulation otherwise (Becker 2009; Becker et al. 2009).

Warm water ensures a relaxing therapeutic effect, reducing muscle tension and improving the blood supply to internal organs. Water at the right temperature creates an optimal environment for relaxation exercises. Water therapy also boosts the production of endorphins, which reduces the pain and greatly improves the mood. The water environment reduces various types of pain, thus offering more opportunities for exercise than would otherwise occur (Becker et al. 2009).

A characteristic feature of the aquatic environment is its unstable substrate, which forces people exercising in the water to engage their stabilizing muscles (core muscles). The horizontal position of the body in the water relieves pressure on the spine, significantly modifying the work of the trunk muscles. The following muscles are responsible for achieving stability: the diaphragm, transverse abdominal muscle, multifocal muscle, pelvic floor muscles and oblique abdominal muscles, forming a ring surrounding the lower trunk from all sides. The collective nature of activity in water as a positive impact on social behavior. Classes in groups build interpersonal contacts and enhance the overall sense of well-being (Becker 2009; Becker et al. 2009).

From the plethora of water rehabilitation methods presented in this article, a decision was made to present the concept of the $\mathrm{Ai}$ Chi method and how it may be currently applied clinically. Attention was also paid to the efficiency of the improvement being carried out in this way.

$\mathrm{Ai}$ Chi is a form of water exercise that combines elements of Tai Chi, Qigong, Watsu, original and classic breathing techniques. The former two are derived from traditional Chinese medicine (Jahnke et al. 2010).

Tai Chi is an ancient martial arts system and a form of meditation. This method is based on the performance of slow and coordinated movements combined with meditation and breathing (Ng and Tsang 2009). The Ai Chi method is not identical with the Tai Chi method in water. Qigong is a system of meditation in motion. The exercise system consists in circular and spiral movements, combined with the displacement of the body's center of gravity and correct breathing (Verhagen et al. 2004).

Watsu is a method that combines advanced techniques of working with the body (joint mobilization and stretching), with shiatsu massage techniques. The latter technique involves the use of acupressure, a method taken from acupuncture - in other words, compressions on special points lying along energy channels, referred to as meridians (Dull 2004). Ai Chi exercises present a collection of simple movements performed in combination with correct breathing. They are conducted while standing in water, arms submerged, using a combination of deep breaths connected with slow, extensive movements of the upper and lower limbs as well as the trunk (Sova and Konno 2003).

Usually, 16 basic items are performed individually, which can be combined into four main exercise groups:

1. breathing in water, 
2. movements with upper limbs,

3. movements with lower limbs,

4. coordinated movements of the upper and lower limbs (Cunha et al. 2010).

The first group of exercises is designed to prepare the body for physical activity while immersed in water. The patient learns to breathe properly, by properly engaging the respiratory muscles. That results in cardiopulmonary stabilization. Then, local movements are introduced in order to activate small followed by major muscle groups within the upper and lower limbs. The ultimate goal is to create coordinated movement with the involvement of the whole body, according to the basic principle of movement instruction - from simple movements to complex movements (Cunha et al. 2010).

The therapeutic effect of the Ai Chi method is achieved through the interaction of smooth movement, breathing, and elements of relaxation and physiological reactions that take place within the body as a result of the techniques mentioned above in an aquatic environment (Castro-Sanchez et al. 2012). The physiological response experienced by the organism include changes in blood pressure and heart rate (a drop in blood pressure and an increase in heart rate in warm water) (Gruner et al. 2009), and even cortisol or aldosterone levels (Sramek et al. 2000). Depending on the water temperature, reflexes may undergo changes related to vasomotor reactions (Weston et al. 1994). In the event of immersion in water at a certain temperature, an increase in tissue metabolism, peripheral catecholamine concentrations and a decrease in blood flow in the brain may be observed (Bleakley and Davison 2010).

The Ai Chi method uses two methods of exercise: static - maintaining the proper position, in which the muscles are maximally stretched, and dynamic exercises - the stretching of the muscles is obtained by performing active movements (Sova and Konno 2003).

While performing $\mathrm{Ai}$ Chi exercises, the muscles are stimulated to alternate stretching, similarly to isometric and stretching exercises. Stretching exercises cause a mechanical increase in the length and elasticity of periarticular contracture, muscles, tendons, joint capsules, and ligaments. This positively affects the structures that comprise the joints. Greater muscle flexibility allows the patient to increase the range of movements performed without damaging the joint capsule or ligaments surrounding the joint (Knudson 2006).

The basis of the Ai Chi method is the use of a large number of equivalent exercises, performed in static conditions - maintaining a stable body position or in dynamic conditions - maintaining a stable body position during movement (Bayraktar et al. 2013).

The Ai Chi method also offers sensorimotor exercise. Performing smooth motion causes the information received by the extra receptors to be sent to the central nervous system. Both the movement and the effect of water stimulates the reflex mechanism of neuromuscular control, which influences the correct positioning of individual parts of the body in relation to each other (Becker 2009).

Sensorimotor training offers better preparation for everyday activities and recreational sports. People who are able to exercise better control over their body position in space will in turn learn new movements faster. Sensorimotor exercises also help reduce the risk of injury by accelerating the response to a dynamic change in body position (Gruber et al. 2007).

In the Ai Chi method, it is important to breathe correctly while exercising. All exercises are connected and complement each other seamlessly. Thanks to the techniques of breathing and concentration, each exercise is performed consciously, at a slow pace. Due to this, the body experiences sufficient time to counteract loading or movements that may be conducted too rapidly or unconsciously, thereby eliminating abnormal motor habits. Exercising involves the patient's nervous system, which must control the course of movement consistently (Lambeck and Bommer 2010). 
Ai Chi training encourages further forms of movement to be performed at an even pace, exercising the same upper or lower limb in the same direction. It requires concentration and synchronization of movements when moving from one form to another. As a result, greater precision of movement is achieved, while neuromuscular coordination is improved. It is important that when the patient performs the exercises, he or she should try maintain good form as far as possible. Thanks to such exercises, increased strength and muscle endurance are just some of the benefits gained. During Ai Chi training, the patient should perform the exercises as much as possible, painlessly with a full range of movement, moving the particular body part against the force of the water resistance. By making more and more correct movements, motor memory is shaped while the functioning of the musculoskeletal system is improved (Sova and Konno 2003).

The ultimate goal of the method is to ensure the correct holistic functioning of the human body by training movement stabilization (Lambeck and Bommer 2010).

\section{Aim}

The purpose of the study was to assess the effectiveness of the $\mathrm{Ai}$ Chi method in the rehabilitation of patients struggling with various medical conditions.

\section{Material and methods}

A systematic review of articles in the PubMed browser from 1994 with keywords "Ai Chi, rehabilitation, water rehabilitation" was used in the article.

\section{Results}

Research conducted using the Ai Chi method in the scientific literature

Balance disorders in seniors

Older people above the age of 65 commonly experience falls (it is assumed that every third person will have suffer from this kind of incident at least once a year). The etiology of these sudden events is complex and mainly includes health problems among seniors associated with sight, hearing, balance or disability disorders of the musculoskeletal system (Moreland et al. 2018).

While training in water, deep muscles are engaged, which are responsible for body balance and coordination, as well as stabilizing the figure. It has been proven that with any limb movement, the first muscle to be engaged is the transverse abdominal muscle (Hodges and Richardson 1996). The transverse abdominal muscle raises the pressure inside the abdominal cavity, which keeps the lumbar region of the spine rigid and stable, thus enabling smooth and more effective coordinated movements of the limbs. The diaphragm is the basic respiratory muscle and, through its connection with the lumbar vertebrae, stabilizes the trunk. In contrast, the pelvic floor muscles, by joining the tailbone, support the maintenance of an upright posture. General stability exercises in water, including Ai Chi, strengthen the muscular corset and stabilize the trunk (Becker 2019, Lambeck and Bommer 2010).

Teixeira et al. evaluated the effectiveness of the Ai Chi method in maintaining a static and dynamic body balance in older adults over 77 who are at high risk of falling. The study involved 30 people who were randomly assigned to test and control groups. The first group, over a period of six weeks, performed exercises in water according to the principles of the Ai Chi method. The participants in the control group were not encouraged to change their current physical activity or social behavior. After 16 exercise sessions, a significant improvement was noted in the ability to maintain body balance (measured by Tinetti Performance-Oriented Mobility Assessment) but only in the study group (Teixeira et al. 2018).

Similar studies were carried out by OlabeSanchez and Martinez-Almagro on a group of 54 people aged 60-85 also with a high risk of falls. After 12 sessions, they manifested a significant improvement in body balance when comparing standard exercises in water 
with the patients practicing the Ai-Chi method (Sanchez and Javier 2018). The effectiveness of this method is also confirmed by the results of Skinner et al. - in the group of 42 seniors there was a reduction in the risk of falls from $38 \%$ to $21 \%$ concurrent with an improvement in equilibrium assessed battery tests (Timed up and Go, Four Square Test, unilateral Step Test) (Skinner et al. 2016).

Publications regarding the use of the Ai-Chi method in patients refer to single cases and refer to post-stroke rehabilitation, improvement in patients with Multiple sclerosis (MS), Parkinson's disease, fibromyalgia Lower back pain (LBP).

\section{Rehabilitation in $L B P$}

The universality of complaints about lower back pain is often associated with a form of disability manifested by a given patient that necessitates the search for new methods of alleviation.

Many years of research have confirmed the thesis that people with lumbosacral spine ailments are characterized by multifocal muscle atrophy, later activation of the transverse abdominal muscle, as well as inappropriate recruitment of the diaphragm together with the pelvic floor muscles (Ebenbichler et al. 2001; Akuthota and Nadler 2004, Barr et al. 2005; Koumantakis et al. 2005). In studies carried out by Hodges and Richardson, it was shown that in people suffering from lower back pain, the deep muscles that stabilize the trunk do not work effectively (Hodges and Richardson 1996). They engage relatively late, compared to their counterparts in people who do not experience pain. Their weakness causes uncontrolled movements of the trunk, which causes the spine be exposed to injuries (O'Sullivan 2005).

Improvement in water in LBP is aimed at strengthening the muscles of the abdomen, buttocks, lower limbs as well as stretching the hamstrings, or the shin muscles, which is supposed to have an analgesic effect on the body. In a study of patients with lower back pain syndromes who participated in rehabilitation activities in water, it was noted that this method of physiotherapy is probably one of the most effective (Ariyoshi et al. 1999).

Camilotti et al. compared the analgesic effect of the Ai Chi method and skull acupuncture - Yamamoto (YNSA) in patients suffering from the lower back syndrome. In the studies, they used the visual analogue scale (VAS) and the Oswestry questionnaire to assess the intensification of pain and disability (Camilotti et al. 2015). There were a few groups (Ai Chi-13, YNSA - 15 people) and a control group of 14 people (waiting for treatment). Inclusion criteria included low back pain lasting at least three months (without pain radiation) in patients aged 33-77 who had not undergone a course of physiotherapy, acupuncture or massage in the 15 days previous to the start of the study. A total of 10 treatments were performed ( $2 \mathrm{x}$ a week), after which the effectiveness of the treatments was assessed. The session in the pool conducted by Ai Chi according to Cunha et al. lasted 30 minutes. Improvement was demonstrated in both groups compared with the control group in terms of pain and disability. The authors draw attention to the small size of the groups and the lack of follow-up assessments, which may slightly undermine the value of the presented results (Cunha et al. 2010).

\section{Movement exercises in multiple sclerosis} Multiple sclerosis (MS) is an autoimmune disease of the CNS, whose background and mechanism of formation remain unexplained. It occurs in young people aged 20-40, often leading to significant physical disability. In MS, the spectrum of symptoms is widespread, most often including visual, sensory, movement, cognitive or urinary disorders. This disease, therefore, affects the psychological and social functioning of the patient. The task of physical rehabilitation including aqua-therapy, is to maintain physical fitness, alleviate symptoms of the illness, and improve the patients' quality of life (Siller et al. 2018).

The studies run by Bayraktar et al. involved 23 patients suffering from MS with a median 
age of 38-39 years with mild disability (1-2 EDSS) and being treated with immunomodulatory drugs. They were divided into two groups: the test (15 people) and control group (8 people). The former underwent an exercise program according to the Ai Chi method ( 30 minutes $2 \mathrm{x}$ a week), while the control group was told to perform specific sets of exercises at home to strengthen the muscles of the upper and lower limbs and the abdomen (2x weeks). The authors showed that the 8-week Ai Chi program improved balance, motor control, the strength of upper and lower limbs and tiredness only in the patients exercising in water. However, the authors draw attention to the limitations in the interpretation of such results in terms of the selection of patients and their limited number. However, they emphasize the pioneering nature of the research and its comprehensiveness (Bayraktar et al. 2013).

Similar studies that evaluated the efficacy of the Ai Chi method in patients with MS were conducted by Castro-Sánchez et al. (CastroSanchez et al. 2012). They included a group of 71 patients with the following inclusion criteria: age $18-75$ years, over 4 points on the VAS scale for two months and scoring $<7.5$ on the EDSS scale and not undertaking any therapy provided within the scope of alternative medicine over the previous three months and with stable disease progression during the previous two months. 36 of the patients participated in aqua-therapy according to the Ai Chi concept, while in the control group, the same therapeutic program was performed in the gym (2x per week for 60 minutes for 20 weeks). The authors evaluated the patients directly before the program and 4 and 10 weeks after completion. They observed significant reductions in the level of pain immediately after the program, which was maintained in control tests only in the group that exercised in water. Also, the level of disability (Barthel scale), depression (Beck's scale), fatigue (scale of fatigue) decreased while the patient's functioning in everyday life improved (MS Impact Scale-29). Up to 10 weeks of observation in a much larger percentage of patients improved by the Ai Chi method than in the control group. The authors emphasize the advantages of the Ai Chi method conducted in water with music as the more effective than conventional kinesitherapy (Castro-Sanchez et al. 2012).

\section{Post-stroke rehabilitation}

Stroke is a significant health concern in today's aging society. It is accepted that the vast majority of those who survive will require full or partial help in the performance of everyday activities due to the concurrence of physical disability. Movement improvement in stroke patients is aimed at improving the motor function of the occupied side of the body in terms of self-care or movement.

Noh et al. studied the effects of water therapy on gait, balance and muscle strength in stroke patients. The inclusion criteria for the patients to take part in the study were as follows: a stroke suffered at least six months after the incident, hemiparesis support with or without medical devices, independent gait, and stable health. The study included 25 patients in total. 12 patients underwent treatment in water, while the other 13 were treated with traditional methods without water. In both groups, the therapy lasted one hour, for eight weeks with a frequency of $3 \mathrm{x}$ a week. The therapy in water included exercises conducted according to the methodology of Ai Chi and Halliwick (20 minutes each). The authors indicate that only the body balance and the range of knee bending in the inferior limb improved after the applied treatment procedure in the group participating in the rehabilitation in water (Noh et al. 2008).

The authors suggest that exercise in water for stroke patients should be performed using these rehabilitation techniques. However, the assessment of their effectiveness definitely requires further research to be conducted on larger research groups.

Rehabilitation of patients with fibromyalgia Fibromyalgia is a chronic non-inflammatory rheumatic disease of soft tissues of unknown etiology characterized by extensive pain in all 
parts of the body (known as quadrants) and lasting at least three months. Also, patients usually report fatigue, sleep disturbances, and anxiety that impede the performance of even the simplest activities or even independent functioning. Physiotherapy, and more specifically exercises performed in water, bring beneficial analgesic effects and thus contribute to an improvement in the patients' (Becker 2009; Rivas Neira 2017).

Pérez-de la Cruz and Lambeck evaluated the effectiveness of rehabilitation using the $\mathrm{Ai}$ Chi method in 20 patients with fibromyalgia (Perez de la Cruz Sagrario and Lambeck Johan 2016). The program included 20 sessions ( $2 x$ a week for 45 minutes each) of the Ai Chi method using 19 positions in the water. After the end of therapy, the patients manifested a significant reduction in pain (VAS) as well as improvement in all areas of the assessed quality of life (SF-36). Despite the impressive results, the authors draw attention to the limitations in their interpretation due to: incomplete data regarding the health of the patients or the lack of a control group, as well as the fact that the evaluation occurred after a certain time had elapsed. Based on the observation of a significant improvement in mood and a high level of satisfaction among the participants in the program, the authors of the work believe that the Ai Chi method has positive effects on the physical and, above all, the psychological well-being of the respondents (Perez de la Cruz Sagrario et al. 2016; Perez de la Cruz Sagrario and Lambeck Johan 2016).

\section{Rehabilitation in Parkinson's disease}

The essence of Parkinson's disease is the disappearance of the dopaminergic cells in the brain, resulting in the patient experiencing a characteristic resting tremor, muscle stiffness, slowness of movement followed by disturbances of gait and posture. It is the second most frequent occurrence neurodegenerative disease occurring in people aged 65 to 90 years in the world after Alzheimer's disease. Improvement in the water is designed primarily to slow down the course of this disease, reduce the symptoms and extend the period of independence, fitness, and activity of the patient (Myers and Capek 2013). Exercises are aimed at improving general physical fitness and physical condition, as well as strengthening the muscles responsible for correct posture. A very important element of the rehabilitation is the elimination of abnormal movement patterns and maintaining correct balance. In the literature, there are four reports on the effectiveness of rehabilitation using the $\mathrm{Ai}$ Chi method in patients with Parkinson's disease.

Pompeu et al. evaluated the effectiveness of exercise in water and its impact on improving the balance and gait of patients with Parkinson's disease (Pompeu et al. 2013). The research group included patients aged 50-60 without any concurrent cognitive impairment who had not undergone any physiotherapy within the previous six months. In their research, they applied a short 5-10 minute program using the Ai Chi method. In these studies, 17 patients at $1-4$ stage Parkinson's disease (from slight to severe motor disability), according to the Hoehn and Yahr scale, took part in 36 water-based sessions lasting 40 minutes each, over a period of three months. The procedure included specialized tests to assess the severity of the disease and movement abilities as well as the patient's maintenance of balance (Time Up and Go, Dynamics Time Index, Berg Balance Scale and Unified Parkinson's Disease Rating Scale). The test was carried out before and after the program. The results showed a significant improvement in the patients' static and dynamic balance. The authors showed that a properly selected program of exercises in water using the Ai Chi method and the properties of the aquatic environment, such as hydrostatic pressure, turbulence and ability to stay on the surface of the water, create favorable conditions for balance training.

Villegas et al. evaluated the effect of the Ai Chi method on quality of life and functional abilities as well as how to maintain posture 
in patients with Parkinson's disease (Pelloso and Israel 2014). Only 15 patients joined the study, divided into two groups - research, exercise ( 8 people) and control (7 people). The patients were aged 49-87 in 2-3 stage Parkinson's disease (from mild to moderate motor disability), according to the Hoehn and Yahr scale, without any concurrent cognitive impairment. The exercises were conducted in water following the Ai Chi method according to Santana et al. (Santana et al.2010) and Cunha et al. (Cunha et al. 2010). Each session lasted 35 minutes, performed twice per week over a period of 12 weeks. Evaluation of symptoms of improvement was carried out immediately after the end of the exercise based on the results of the functional scale. This scale is used to assess various aspects of the disease (Unified Parkinson's Disease Rating Scale- UPDRS) alongside a quality of life questionnaire (PDQ-39) and an analysis of body posture (using the SAPO program). The authors revealed only a small statistical improvement in the patients' daily activity as one of the assessed elements of the general functioning of the patient according to the UPDRS scale. The authors treat their research as groundbreaking due to the methodology and the proposed test procedure (Cunha et al. 2010).

Perez-de la Cruz et al. in his study included 15 patients with 1-3 stage Parkinson's disease (from slight to moderate motor disability), according to the Hoehn and Yahr scale, without any concurrent cognitive disorders aged 51-81 years. Aqua-therapy according to the $\mathrm{Ai} \mathrm{Chi}$ method included 19 exercises and lasted 30 minutes ( $2 \mathrm{x}$ week) over ten weeks. An evaluation of the effectiveness of the program was conducted immediately after the entire rehabilitation session as well as one month following its completion. Statistical improvement in terms of gait, balance, and pain was demonstrated, which persisted during the monthly observation period. The authors, due to the small number of patients and the lack of a control group, encourage further research in this area. They believe that the
Ai Chi method is a promising rehabilitation technique and can be used in patients in the early stages of the disease (Perez de la Cruz Sagrario et al. 2016; Perez de la Cruz Sagrario and Lambeck Johan 2016).

The latest randomized trials conducted by Kurt et al. (Kurt et al. 2018) involved 40 patients with mild and moderate motor disability diagnosed according to the Hoehn and Yahr scale in the course of Parkinson's disease. The authors demonstrated a greater improvement in movement, balance and quality of life (Time Balance and Dynamics Time Index, Berg Balance Scale and Unified Parkinson's Disease Rating Scale, Parkinson's Disease Questionnaire-39) in patients who did ( 5 weeks) Ai Chi training in water compared with those who performed a similar set of exercises but outside of water. The authors recommend that the Ai Chi method should be one of the methods of rehabilitation in patients with mild to moderate disease severity.

\section{Discussion}

The use of water for healing purposes has its roots in the beginnings of the history of medicine. It is also difficult to demonstrate the impact of physical exercise on improving and maintaining health. Today, it is known that this applies to the body not only from its structure and function but also significantly affects the mental health of every human being. Eliminating pain, movement limitations and, in turn, the possibility of full relaxation has a dramatic impact on the quality of our life. Movement exercises in water provide an interesting combination of therapeutic effects on the human body due to the various mechanisms described in this work. Due to their specific nature, exercises in water can be used in different groups of patients, including in healthy people. It can, therefore, be said that they constitute an interesting physiotherapeutic and prophylactic proposition.

The Ai Ci method is a relatively new rehabilitation technique carried out in water. The underlying assumption is that it ensures improvement in body balance, mobility, strength, 
coordination, proprioception in connection with relaxation and proper breathing. These factors are evidence of the effectiveness of this therapeutic method. The presented works emphasize the beneficial effect of the Ai Chi method on the maintenance of static and dynamic body balance, especially in elderly people. In contrast, the assessment of the effectiveness of rehabilitation in patients after stroke, patients with MS, Parkinson's disease, fibromyalgia or LBP is difficult at this stage of the research. Research groups have so far involved few participants selected non-homogeneously, and the presented results have only been sporadically compared to controls. Evaluation with the use of numerous specialist scales and questionnaires is carried out mainly before and after the improvement. Unfortunately, even the positive evidence presented by many authors regarding the improvement of motor functioning or the quality of life of a patient requires further verification in terms of duration. The applied research procedure with the use of the $\mathrm{Ai}$ Chi method also requires standardization in the number of movements repeated, the duration of each session and their frequency in the week as well as the duration of the improvement itself.

\section{Conclusions}

Authors of this review deem that Ai Chi method should be used in therapy for patients with balance disorder in seniors, lower back pain, multiple sclerosis, stroke, fibromyalgia, Parkinson's disease equally with conventional kinesiotherapy.

\section{REFERENCES}

Akuthota V., Nadler SF. (2004) 'Core strengthening' Arch Phys Med Rehabil. 85(3), Suppl 1, pp. S86-92.

Ariyoshi M., Sonoda K., Nagata K., et al. (1999) 'Efficacy of aquatic exercises for patients with low-back pain.' Kurume Med J. 46(2), pp. 91-96.
Barr KP., Griggs M., Cadby T. (2005) 'Lumbar stabilization: core concepts and current literature', Part 1 . Am J Phys Med Rehabil. 84(6) pp. 473-480.

Bayraktar D., Guclu-Gunduz A., Yazici G., et al. (2013) 'Effects of Ai-Chi on balance, functional mobility, strength and fatigue in patients with multiple sclerosis: a pilot study.' NeuroRehabilitation. 33(3) pp. 431-437. Becker B. (2009) 'Aquatic therapy: scientific foundations and clinical rehabilitation applications.' PM R., 1(9) pp. 859-872.

Becker B., Hildenbrand K., Whitcomb R., et al. (2009) 'Biophysiologic Effects of Warm Water Immersion.' Int J Aquat Res Educ., 3(1). Bleakley CM., Davison GW. (2010) 'What is the biochemical and physiological rationale for using cold-water immersion in sports recovery? A systematic review.' Br J Sports Med. 44(3) pp. 179-187.

Castro-Sánchez AM., Matarán-Peñarrocha GA., Lara-Palomo I., et al. (2012) 'Hydrotherapy for the treatment of pain in people with multiple sclerosis: a randomized controlled trial.' Evidence-Based Complement Altern Med ECAM. 2012:473963.

Camilotti BM., Leite N., Alberti D., et al. (2015) 'Effects of Ai Chi and Yamamoto new scalp acupuncture on chronic low back pain.' Fisioter Em Mov. 28(4) pp. 723-730.

Cunha MCB., Alonso AC., Mesquita E Silva T, et al. (2010) 'Ai Chi: efeitos do relaxamento aquático no desempenho funcional e qualidade de vida em idosos.' Fisioter Em Mov Impresso. 23(3) pp. 409-417.

Dull H. (2004) 'Watsu: Freeing the Body in Water.' Trafford Publishing.

Ebenbichler GR., Oddsson LI., Kollmitzer J., (2001) Erim Z. 'Sensory-motor control of the lower back: implications for rehabilitation.' Med Sci Sports Exerc. 33(1l) pp. 1889-1898. Gruber M., Gruber SBH., Taube W., et al. (2007) 'Differential effects of ballistic versus sensorimotor training on rate of force development and neural activation in humans.' J Strength Cond Res. 21(1) pp. 274-282.

Gruner Svealv B., Cider A., Tang MS., et al. (2009) 'Benefit of warm water immersion 
on biventricular function in patients with chronic heart failure.' Cardiovasc Ultrasound. 6 pp. 7-33.

Hodges PW., Richardson CA. (1996) 'Inefficient muscular stabilization of the lumbar spine associated with low back pain. A motor control evaluation of transversus abdominis'. Spine. 21(22) pp. 2640-2650.

Jahnke RA., Larkey LK., Rogers C. (2010) 'Dissemination and benefits of a replicable Tai Chi and Qigong program for older adults.' Geriatr Nur (Lond)., 31(4) pp. 272-280.

Knudson D. (2006) The biomechanics of stretching. J Exerc Sci Physiother. 2006 pp. 2-3.

Koumantakis GA., Watson PJ., Oldham JA. (2005) 'Trunk muscle stabilization training plus general exercise versus general exercise only: randomized controlled trial of patients with recurrent low back pain.' Phys Ther. 85(3) pp. 209-225.

Kurt EE., Büyükturan B., Büyükturan Ö., et al. (2018) 'Effects of Ai Chi on balance, quality of life, functional mobility, and motor impairment in patients with Parkinson's disease.' Disabil Rehabil. 40(7) pp. 791-797. Lambeck J., Bommer A. (2010) 'Clinical Ai Chi.' Applications in Clinical Practice. 26. Moreland BL., Durbin LL., Kasper JD., et al. (2018)'Rehabilitation utilization for falls among community-dwelling older adults in the United States in the National Health and Aging Trends Study.' Arch Phys Med Rehabil. Myers KW., Capek D. (2013) 'Aquatic Therapy and Alzheimer's Disease.' Annals of long term care.

Ng BHP., Tsang HWH. (2009) 'Psychophysiological outcomes of health qigong for chronic conditions: a systematic review.' Psychophysiology., 46(2) pp. 257-269.

Noh DK., Lim J-Y., Shin H-I., et al. (2008) 'The effect of aquatic therapy on postural balance and muscle strength in stroke survivors-a randomized controlled pilot trial.' Clin Rehabil. 22(10-11) pp. 966-976.

O'Sullivan P. (2005) 'Diagnosis and classification of chronic low back pain disorders: maladaptive movement and motor control impairments as underlying mechanism.' Man Ther. 10(4) pp. 242-255.

Pelloso VI., Israel VL. (2014) 'Effect of the Ai-Chi Method on Functional Activity, Quality of Life, and Posture in Patients With Parkinson Disease.' Top Geriatr Rehabil., 40(7) pp. 79l-797.

Pérez-de la Cruz S., García Luengo AV., Lambeck J. (2016) 'Effects of an Ai Chi fall prevention programme for patients with Parkinson's disease.' Neurol Barc Spain. 31(3) pp. 176-182.

Pérez de la Cruz S., Lambeck J. (2016) 'A new approach to the improvement of quality of life in fibromyalgia: a pilot study on the effects of an aquatic Ai Chi program.' Int J Rheum Dis. 21(8) pp. 1525-1532.

Pompeu JE., Gimenes RO., Pereira RP., et al. (2013) 'Effects of aquatic physical therapy on balance and gait of patients with Parkinson's disease.' J Health Sci Inst. 31(2) pp. 201-204. Rivas Neira S., Pasqual Marques A., Pegito Pérez I., et al. (2017) 'Effectiveness of Aquatic Therapy vs Land-based Therapy for Balance and Pain in Women with Fibromyalgia: a study protocol for a randomised controlled trial.' BMC Musculoskelet Disord. 18.

Sánchez O., Javier P. (2013) 'Repercusión del Ai Chi en el equilibrio de las personas mayores.' Universidad Católica San Antonio. Santana JS de, Almeida APG de, Brandão PMC. (2010) 'The effect of Ai Chi method in fybromialgic patients.' Ciênc Amp Saúde Coletiva. 15. pp. 1433-1438.

Siller N., Kuhle J., Muthuraman M., et al. (2018) 'Serum neurofilament light chain is a biomarker of acute and chronic neuronal damage in early multiple sclerosis.' Mult Scler Houndmills Basingstoke Engl.

Skinner EH., Dinh T., Hewitt M., et al. (2016) An Ai Chi-based aquatic group improves balance and reduces falls in community-dwelling adults: A pilot observational cohort study.' Physiotherapy Theory Pract. 32(8) pp. 581-590.

Sova R., Konno J. (2003) 'Ai Chi Balance, Harmony \& Healing. 2nd Ed.' DSL ltd. 
Srámek P., Simecková M., Janský L., et al. (2000) 'Human physiological responses to immersion into water of different temperatures.' Eur J Appl Physiol. 81(5) pp. 436-442.

Teixeira R., Perez L., Lambeck J., et al. (2011) 'The Influence of Ai Chi on Balance and Fear of Falling in Older Adults: A Randomized Clinical Trial.' Physiotherapy.

Weston M., Taber C., Casagranda L., et al. (1994) 'Changes in local blood volume during cold gel pack application to traumatized ankles.' J Orthop Sports Phys Ther. (4) pp. 197-199.

Verhagen AP., Immink M., van der Meulen A., et al. 'The efficacy of Tai Chi Chuan in older adults: a systematic review.' Fam Pract. 21(1) pp. 107-113. 